\title{
FUS/CREB3L2 Fusion Protein
}

National Cancer Institute

\section{Source}

National Cancer Institute. FUS/CREB3L2 Fusion Protein. NCI Thesaurus. Code C99284.

A fusion protein encoded by the FUS/CREB3L2 fusion gene. This protein is comprised of approximately half the RNA-binding protein FUS fused to the DNA-binding basic domain and leucine zipper dimerization domain of the cyclic AMP-responsive element-binding protein 3-like protein 2 . 